\title{
A new species of taipan (Elapidae: Oxyuranus) from central Australia
}

\author{
PAUL DOUGHTY ${ }^{1,2^{*}}$, BRAD MARYAN ${ }^{1,3}$, STEPHEN C. DONNELLAN $^{4} \&$ MARK N. HUTCHINSON $^{5}$ \\ ${ }^{\prime}$ Department of Terrestrial Vertebrates, Western Australian Museum, 49 Kew Street, Welshpool WA 6106, Australia \\ 2e-mail:Paul.Doughty@museum.wa.gov.au \\ 3e-mail: Brad.Maryan@museum.wa.gov.au \\ ${ }^{4}$ Evolutionary Biology Unit, South Australian Museum, North Terrace, Adelaide SA and Australian Centre for Evolutionary Biology \\ and Biodiversity, University of Adelaide, Adelaide SA 5000, Australia; e-mail: Donnellan.Steve@saugov.sa.gov.au \\ ${ }^{5}$ Herpetology Section, South Australian Museum, North Terrace, Adelaide SA and School of Earth and Environmental Sciences, Uni- \\ versity of Adelaide, Adelaide SA 5000, Australia; e-mail: hutchinson.mark@saugov.sa.gov.au \\ *corresponding author: Paul.Doughty@museum.wa.gov.au
}

\begin{abstract}
Snakes in the Australo-Papuan elapid genus Oxyuranus are considered to be the most venomous species in the world. A recent expedition to the central ranges of Western Australia discovered a third species, which is described here from the only known specimen. Molecular genetic analyses using mitochondrial nucleotide sequences places the new species as the sister lineage of the two described Oxyuranus species, with all three species united by a long branch that also separates them from the nearest of the brown snakes species (Pseudonaja) to which the taipans are close relatives. Morphologically, the new species shares with the other Oxyuranus an undivided anal scale, high midbody scale row (21) and ventral scale (250) counts, but differs in having a single primary temporal scale and fewer lower labials (six). Maximum body size and venom potency are unknown. The discovery of a third species of taipan in the remote central ranges of Australia underlines the paucity of collecting from this region.
\end{abstract}

Key words: Elapidae, mitochondrial DNA, species boundary, snake, taipan

\section{Introduction}

Australian elapid systematics has advanced in recent years largely through phylogenetic analysis of new molecular and detailed morphological data (e.g., Smith 1982, Keogh 1998, 1999; Keogh et al. 1998,2000; Slowinski \& Keogh 2000; Skinner et al. 2005; Wüster et al. 2005). Recently, subtly distinct, cryptic species have been described from widespread highly variable taxa (e.g., Keogh \& Smith 1996; Aplin \& Donnellan 1999). However, it has been very rare to discover new species of large-bodied Australian snakes readily distinguished by traditional morphological features (but see Smith 1981 for a python example).

The two described species of Oxyuranus are among the most venomous snakes in the world, with $O$. microlepidotus (McCoy 1879) ranked the most and O. scutellatus (Peters 1867) the third most venomous (after Pseudonaja textilis) (Broad et al. 1979). These rankings were based on laboratory tests of venom toxicities on mice and do not reflect actual human fatalities from snake bites. In essence, the high venom potency of taipans is believed to be an adaptation to cope with potentially harmful mammal prey, upon which they feed almost exclusively (Shine \& Covacevich 1983). The potential danger of $O$. scutellatus and to a lesser degree O. microlepidotus, has been well publicised (Worrell 1958; Stackhouse 1970; Jones 1977). Despite the high profile of taipans, and that the two species were described over 125 years ago, documentation of their ecology, 
behaviour, reproductive biology, relationships and distribution has been slow (Covacevich et al. 1981; Covacevich 1987; Shine \& Covacevich 1983; Skinner et al. 2005). More recently, observations of captive taipans (Barnett 1978, 1986) have complemented data on reproduction and feeding from available museum specimens (Shine and Covacevich 1983).

The inland taipan, O. microlepidotus, occurs in two populations, one in the channel country of arid southwestern Queensland and northeastern South Australia, and a second on the cracking clay plains north and east of Coober Pedy in central South Australia (Fig. 1). In contrast, the coastal taipan, O. scutellatus, occurs in a wider variety of habitats including sugarcane fields and woodlands along the eastern and northern coast of Australia in separate populations in the northwest Kimberley region of Western Australia, Northern Territory and from Cape York to northern New South Wales (Fig. 1). The species also occurs in a range of savannah habitats in southern New Guinea (O'Shea 1996).

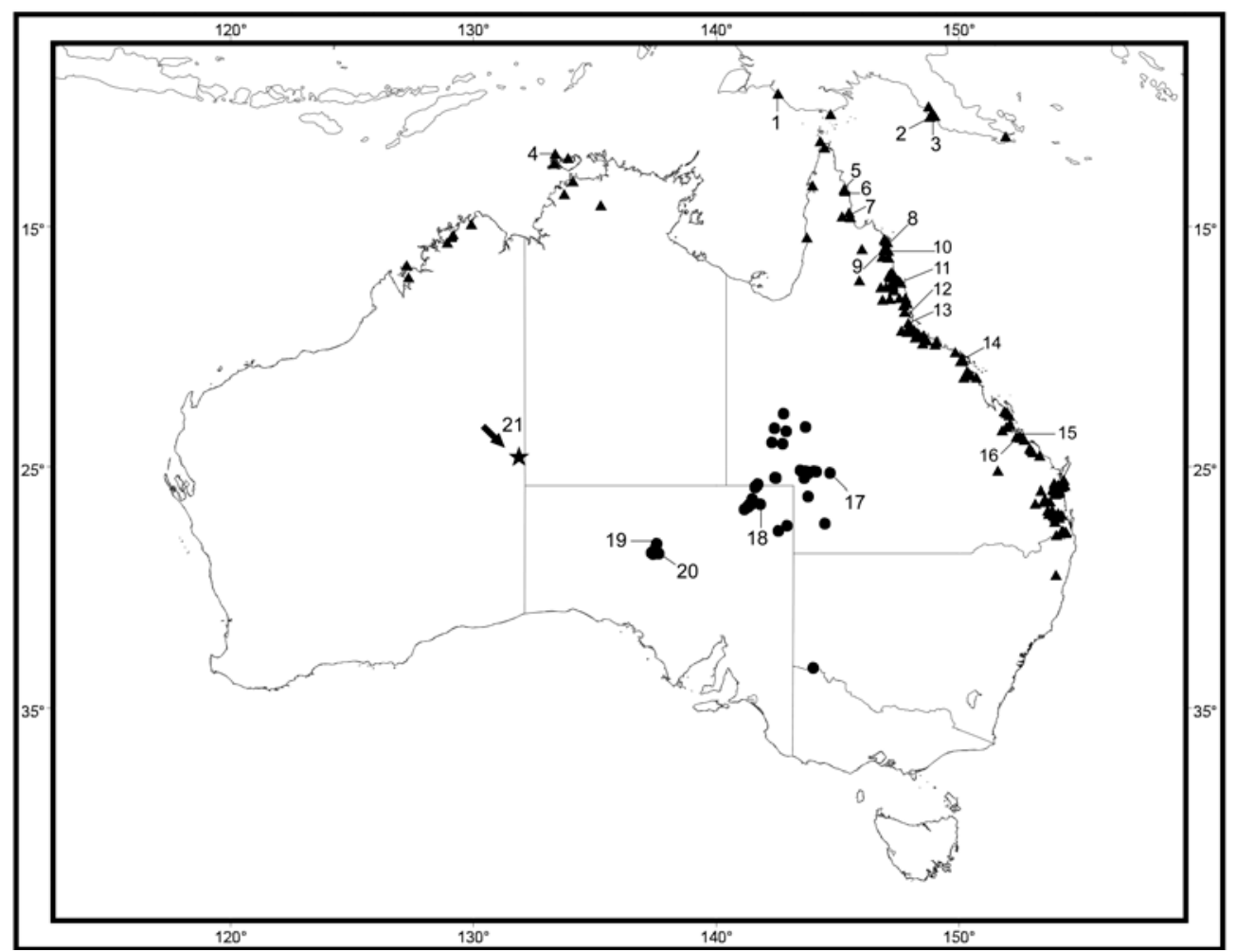

FIGURE 1. Distribution of Oxyuranus scutellatus, O. microlepidotus and O. temporalis sp. nov. in Australia and New Guinea from McCoy (1879) and records in the collections of the Australian, Northern Territory, Queensland, South Australian and Western Australian Museums, and the Australian National Wildlife Collection (CSIRO). Numbered collection locations are detailed in Table 1 and indicate sites sampled for the molecular genetic analyses. Oxyuranus microlepidotus $\bullet$, O. scutellatus $\mathbf{\Lambda}$, and $O$. temporalis $\star$.

Recent efforts to map biodiversity on a continental scale in Australia have led to the identification of several areas in eastern Western Australia that are under-surveyed for biological diversity (How \& Cowan 2006). A recent targeted survey to the central ranges of Western Australia to address the lack of biological survey in eastern Western Australia resulted in the discovery of a third species of taipan. Only one immature animal was captured and at the time was presumed to be a western brown snake (Pseudonaja nuchalis). Closer examination of the specimen in the laboratory indicated that it possessed several key characters found either in Oxyuranus or Pseudonaja (i.e., similar colouration, undivided anal scale, single primary temporal scale). Molecular genetic analysis indicates the specimen is a distinctive member of Oxyuranus, resolving the ambiguity of the odd combination of morphological characters. We herein describe the new species based on the only known specimen and redefine Oxyuranus to accommodate the new taxon. 


\section{Methods}

\section{Molecular genetic analyses}

Mitochondrial ND4 sequence for the holotype (WAM R166250) was obtained by PCR and direct sequencing following the molecular genetic methods of Skinner et al. (2005). This sequence was aligned by eye with other ND4 sequences which comprised a) a subset of sequences of Pseudonaja, published by Skinner et al. (2005), and selected to represent the diversity within the major clades found by Skinner et al. (2005) within each species; b) 7 published Oxyuranus sequences (Skinner et al. 2005, Wüster et al. 2005) and a further 15 Oxyuranus sequenced in the present study; c) sequences from three outgroups - Pseudechis australis (Skinner et al. 2005) and Neelaps calonotus and Vermicella intermedia donated by J.S. Keogh; and d) and a further four P. nuchalis (SAMA R62113-4, WAM R166246-7; GenBank accession EF210837-40) which were collected on the same survey and in the same region as WAM R166250. Details of specimens sequenced in the present study and obtained from published sources are presented in Table 1.

TABLE 1. Specimens of Oxyuranus and outgroups examined for molecular genetic analysis. Numbers in locality column for Oxyuranus refer to sample locations on Fig. 1.

\begin{tabular}{|c|c|c|c|}
\hline Species & Locality & Voucher & GenBank \\
\hline \multirow[t]{18}{*}{ O. scutellatus } & 1 - Merauke, West Papua Indonesia & WW274 & AY340788 \\
\hline & 2 - Port Moresby, PNG & AMS R119562 & DQ098438 \\
\hline & 3 - Central Prov, PNG & WW1256 & AY340788 \\
\hline & 4 - Bathurst Island & NTM R17009 & DQ098436 \\
\hline & 5 - Iron Range & АBTC77163 & EF210831 \\
\hline & 6 - Lockhart River Road & ABTC77161 & EF210828 \\
\hline & 7 - McIlwraith Ranges & ANWCR05246 & EF210833 \\
\hline & 8 - Cooktown & АBTC82464 & EF210825 \\
\hline & 9 - Julatten & ANWCR06772 & EF210834 \\
\hline & 10 - Cairns & WW1199, 1132 & AY340788 \\
\hline & 10 - Cairns & АВTC76944 & EF210829 \\
\hline & 11 - Bingil Bay & ABTC77160 & EF210826 \\
\hline & 12 - Jourama Falls & АВTC 81245 & EF210836 \\
\hline & 13 - Crystal Creek & АВТС 82991 & EF210832 \\
\hline & $14-$ Mt Ossa & АВTC32087 & DQ098437 \\
\hline & 15 - Gladstone & АВТС92267 & EF210835 \\
\hline & 16 - Mt Larcom & SAMAR55909 & EF210830 \\
\hline & Queensland & SAMAR24408 & EF210827 \\
\hline \multirow[t]{4}{*}{ O. microlepidotus } & 17 - Windorah & АBTC 82463 & EF210824 \\
\hline & 18 - Goyders Lagoon & SAMAR20583, 26876 & $\begin{array}{l}\text { DQ098434, } \\
\text { EF210823 }\end{array}$ \\
\hline & 19 - 20k NE Coober Pedy & SAMA R49883 & DQ098435 \\
\hline & 20 - 30k E Coober Pedy & ABTC64860 & EF210822 \\
\hline O. temporalis & 21 - Walter James Range & WAM R166250 & EF210821 \\
\hline Vermicella intermedia & Darwin & SAMAR25672 & EF210842 \\
\hline Neelaps calonotus & Muchea Muchea Air Weapons Range & WAMR152960 & EF210841 \\
\hline
\end{tabular}


TABLE 2. Specimens of Oxyuranus and outgroups examined morphologically. Localities without a State designation are in WA.

\begin{tabular}{|c|c|c|c|}
\hline Registration no. & Locality & Latitude & Longitude \\
\hline \multicolumn{4}{|c|}{ Oxyuranus temporalis } \\
\hline WAM R166250 & Walter James Range & $24^{\circ} 40^{\prime} 06^{\prime \prime S}$ & $128^{\circ} 45^{\prime} 52^{\prime \prime} \mathrm{E}$ \\
\hline \multicolumn{4}{|c|}{ Oxyuranus microlepidotus } \\
\hline QM J41471/8 & Morney Plain, 100km W Windorah, Qld & $25^{\circ} 22^{\prime} 00^{\prime} \mathrm{S}$ & $141^{\circ} 28^{\prime} 00^{\prime \prime} \mathrm{E}$ \\
\hline QM J49901 & unknown locality & & \\
\hline QM J50268 & captive bred & & \\
\hline SAMA R04284 & 4.8km S Planet HS, Qld & $25^{\circ} 55^{\prime} 00^{\prime \prime} \mathrm{S}$ & $141^{\circ} 07^{\prime} 00^{\prime \prime} \mathrm{E}$ \\
\hline SAMA R04289 & Mt Leonard Stn, Qld & $25^{\circ} 41^{\prime} 00^{\prime \prime} \mathrm{S}$ & $140^{\circ} 45^{\prime} 00^{\prime \prime} \mathrm{E}$ \\
\hline SAMA R04303 & Mt Leonard HS, Qld & $25^{\circ} 41^{\prime} 00^{\prime \prime} \mathrm{S}$ & $140^{\circ} 45^{\prime} 00^{\prime \prime} \mathrm{E}$ \\
\hline SAMA R04719-21 & Planet HS, Qld & $25^{\circ} 52^{\prime} 00^{\prime \prime} \mathrm{S}$ & $141^{\circ} 07^{\prime} 00^{\prime \prime} \mathrm{E}$ \\
\hline SAMA R14618 & Innamincka area, $\mathrm{SA}$ & $27^{\circ} 45^{\prime} 00^{\prime \prime} \mathrm{S}$ & $140^{\circ} 44^{\prime} 00^{\prime \prime} \mathrm{E}$ \\
\hline SAMA R14649 & near Birdsville Track, SA & $26^{\circ} 02^{\prime} 00^{\prime \prime} \mathrm{S}$ & $139^{\circ} 19^{\prime} 00^{\prime \prime} \mathrm{E}$ \\
\hline SAMA R19201 & 20km N Moomba, SA & $27^{\circ} 59^{\prime} 00^{\prime \prime} \mathrm{S}$ & $140^{\circ} 21^{\prime} 00^{\prime \prime} \mathrm{E}$ \\
\hline SAMA R20583 & Goyders Lagoon, SA & $26^{\circ} 46^{\prime} 00^{\prime \prime} \mathrm{S}$ & $139^{\circ} 08^{\prime} 00^{\prime \prime} \mathrm{E}$ \\
\hline SAMA R24128 & 35km N Clifton Hills HS, SA & $26^{\circ} 49^{\prime} 00^{\prime \prime} \mathrm{S}$ & $139^{\circ} 01^{\prime} 00^{\prime \prime} \mathrm{E}$ \\
\hline SAMA R26876 & Goyders Lagoon, SA & $26^{\circ} 46^{\prime} 00^{\prime \prime} \mathrm{S}$ & $139^{\circ} 08^{\prime} 00^{\prime \prime} \mathrm{E}$ \\
\hline SAMA R26942 & Goyders Lagoon, SA & $26^{\circ} 33^{\prime} 00^{\prime \prime} \mathrm{S}$ & $139^{\circ} 10^{\prime} 00^{\prime \prime} \mathrm{E}$ \\
\hline SAMA R35074 & Goyders Lagoon, SA & $26^{\circ} 33^{\prime} 00^{\prime \prime} \mathrm{S}$ & $139^{\circ} 10^{\prime} 00^{\prime \prime} \mathrm{E}$ \\
\hline SAMA R40464 & $61 \mathrm{~km}$ NNE Coober Pedy, SA & $28^{\circ} 33^{\prime} 00^{\prime \prime} \mathrm{S}$ & $134^{\circ} 55^{\prime} 00^{\prime \prime} \mathrm{E}$ \\
\hline SAMA R40733 & near Clifton Hills Stn, SA & $27^{\circ} 01^{\prime} 00^{\prime \prime} \mathrm{S}$ & $138^{\circ} 50^{\prime} 00^{\prime \prime} \mathrm{E}$ \\
\hline SAMA R40985 & Tomcat Hill, Coober Pedy, SA & $29^{\circ} 01^{\prime} 00^{\prime \prime} \mathrm{S}$ & $134^{\circ} 45^{\prime} 00^{\prime \prime} \mathrm{E}$ \\
\hline SAMA R42484 & 7km N Coober Pedy, SA & $28^{\circ} 57^{\prime} 00^{\prime \prime} \mathrm{S}$ & $134^{\circ} 47^{\prime} 00^{\prime \prime} \mathrm{E}$ \\
\hline SAMA R44080 & 36km N Coober Pedy, SA & $28^{\circ} 42^{\prime} 00^{\prime \prime} \mathrm{S}$ & $134^{\circ} 52^{\prime} 00^{\prime \prime} \mathrm{E}$ \\
\hline SAMA R47573 & Goyders Lagoon, SA & $26^{\circ} 46^{\prime} 00^{\prime \prime} \mathrm{S}$ & $139^{\circ} 08^{\prime} 00^{\prime \prime} \mathrm{E}$ \\
\hline SAMA R49764 & 8km NNW Coober Pedy, SA & $28^{\circ} 58^{\prime} 00^{\prime \prime} \mathrm{S}$ & $134^{\circ} 41^{\prime} 00^{\prime \prime} \mathrm{E}$ \\
\hline SAMA R49883 & 20km NE Coober Pedy, SA & $28^{\circ} 51^{\prime} 00^{\prime \prime} \mathrm{S}$ & $134^{\circ} 53^{\prime} 00^{\prime \prime} \mathrm{E}$ \\
\hline \multicolumn{4}{|c|}{ Oxyuranus scutellatus } \\
\hline SAMA R00358 & Coen River, Qld & $13^{\circ} 52^{\prime} 00^{\prime \prime} \mathrm{S}$ & $142^{\circ} 51^{\prime} 00^{\prime \prime} \mathrm{E}$ \\
\hline SAMA R04365 & Mackay, Qld & $21^{\circ} 09^{\prime} 00^{\prime \prime} \mathrm{S}$ & $149^{\circ} 11^{\prime} 00^{\prime \prime} \mathrm{E}$ \\
\hline SAMA R06754 & Cairns, Qld & $16^{\circ} 55^{\prime} 00^{\prime \prime} \mathrm{S}$ & $145^{\circ} 46^{\prime} 00^{\prime \prime} \mathrm{E}$ \\
\hline SAMA R09964-7 & near Cairns, Qld & $16^{\circ} 42^{\prime} 00^{\prime \prime} \mathrm{S}$ & $145^{\circ} 38^{\prime} 00^{\prime \prime} \mathrm{E}$ \\
\hline SAMA R24518 & Funnel Creek S Mackay, Qld & $21^{\circ} 48^{\prime} 00^{\prime \prime} \mathrm{S}$ & $148^{\circ} 55^{\prime} 00^{\prime \prime} \mathrm{E}$ \\
\hline SAMA R55909 & Mt Larcom area, Qld & $23^{\circ} 48^{\prime} 00^{\prime \prime} \mathrm{S}$ & $150^{\circ} 58^{\prime} 00^{\prime \prime} \mathrm{E}$ \\
\hline WAM R46865 & Prince Regent River & $15^{\circ} 07^{\prime} 00^{\prime \prime S}$ & $125^{\circ} 33^{\prime} 00^{\prime \prime} \mathrm{E}$ \\
\hline WAM R60666 & 6km WNW Amax Camp & $14^{\circ} 49^{\prime} 00^{\prime \prime S}$ & $125^{\circ} 47^{\prime} 00^{\prime \prime} \mathrm{E}$ \\
\hline WAM R64845 & Mitchell Plateau & $14^{\circ} 52^{\prime} 00^{\prime \prime S}$ & $125^{\circ} 49^{\prime} 00^{\prime \prime} \mathrm{E}$ \\
\hline WAM R71206 & 40km S Cooktown, Qld & $15^{\circ} 48^{\prime} 00^{\prime \prime S}$ & $145^{\circ} 14^{\prime} 00^{\prime \prime} \mathrm{E}$ \\
\hline
\end{tabular}


TABLE 2 (continued)

\begin{tabular}{|c|c|c|c|}
\hline Registration no. & Locality & Latitude & Longitude \\
\hline WAM R77024-5 & Mitchell Plateau & $14^{\circ} 49^{\prime} 15^{\prime \prime S}$ & $125^{\circ} 50^{\prime} 30^{\prime \prime} \mathrm{E}$ \\
\hline WAM R103731 & Koolan Island & $16^{\circ} 09^{\prime} 00^{\prime \prime S}$ & $123^{\circ} 45^{\prime} 00^{\prime \prime} \mathrm{E}$ \\
\hline WAM R106029 & Koolan Island & $16^{\circ} 09^{\prime} 00^{\prime \prime S}$ & $123^{\circ} 45^{\prime} 00^{\prime \prime} \mathrm{E}$ \\
\hline WAM R146363-4 & Kalumburu & $14^{\circ} 18^{\prime} 00^{\prime \prime S}$ & $126^{\circ} 38^{\prime} 00^{\prime \prime} \mathrm{E}$ \\
\hline \multicolumn{4}{|l|}{ Pseudonaja nuchalis } \\
\hline WAM R24679 & Warburton & $26^{\circ} 08^{\prime} 00^{\prime \prime S}$ & $126^{\circ} 35^{\prime} 00^{\prime \prime} \mathrm{E}$ \\
\hline WAM R31325 & 50km W Windy Corner & $23^{\circ} 30^{\prime} 00^{\prime \prime} \mathrm{S}$ & $124^{\circ} 43^{\prime} 00^{\prime \prime} \mathrm{E}$ \\
\hline WAM R53588 & 10km S Jackie Junction & $25^{\circ} 46^{\prime} 00^{\prime \prime} \mathrm{S}$ & $126^{\circ} 41^{\prime} 00^{\prime \prime} \mathrm{E}$ \\
\hline WAM R55966 & 52km S Wiluna & $25^{\circ} 46^{\prime} 00^{\prime \prime S}$ & $125^{\circ} 56^{\prime} 00^{\prime \prime} \mathrm{E}$ \\
\hline WAM R83670 & 40km S Balgo & $20^{\circ} 31^{\prime} 00^{\prime \prime S}$ & $127^{\circ} 55^{\prime} 00^{\prime \prime} \mathrm{E}$ \\
\hline WAM R95036 & Lake Winifred & $22^{\circ} 41^{\prime} 00^{\prime \prime S}$ & $123^{\circ} 32^{\prime} 00^{\prime \prime} \mathrm{E}$ \\
\hline WAM R110560 & 7-8km WNW Point Salvation & $28^{\circ} 12^{\prime} 00^{\prime \prime S}$ & $123^{\circ} 35^{\prime} 00^{\prime \prime} \mathrm{E}$ \\
\hline WAM R144978 & Doon Doon HS & $16^{\circ} 18^{\prime} 45^{\prime \prime S}$ & $128^{\circ} 14^{\prime} 30^{\prime \prime} \mathrm{E}$ \\
\hline WAM R166246 & 18.3km ENE Blackstone & $25^{\circ} 55^{\prime} 51^{\prime \prime} \mathrm{S}$ & $128^{\circ} 26^{\prime} 58^{\prime \prime} \mathrm{E}$ \\
\hline WAM R166247 & 3.3km S Gill Pinnacle & $24^{\circ} 55^{\prime} 22^{\prime \prime S}$ & $128^{\circ} 46^{\prime} 36^{\prime \prime} \mathrm{E}$ \\
\hline \multicolumn{4}{|l|}{ Pseudechis australis } \\
\hline WAM R22178 & Warburton & $2608^{\prime} 00 " \mathrm{~S}$ & $126^{\circ} 35^{\prime} 00^{\prime \prime} \mathrm{E}$ \\
\hline WAM R22731-2 & Kumarina & $24^{\circ} 42^{\prime} 00^{\prime \prime} \mathrm{S}$ & $119^{\circ} 36^{\prime} 00^{\prime \prime} \mathrm{E}$ \\
\hline WAM R31020 & Tom Price & $22^{\circ} 42^{\prime} 00^{\prime \prime S}$ & $117^{\circ} 47^{\prime} 00^{\prime \prime} \mathrm{E}$ \\
\hline WAM R48755 & $30 \mathrm{~km}$ N Neale Junction & $28^{\circ} 03^{\prime} 00^{\prime \prime} \mathrm{S}$ & $126^{\circ} 00^{\prime} 00^{\prime \prime} \mathrm{E}$ \\
\hline WAM R60909 & 10km W One Arm Point & $16^{\circ} 27^{\prime} 00^{\prime \prime} \mathrm{S}$ & $122^{\circ} 59^{\prime} 00^{\prime \prime} \mathrm{E}$ \\
\hline WAM R78977 & Eneabba & $29^{\circ} 49^{\prime} 00^{\prime \prime} \mathrm{S}$ & $115^{\circ} 16^{\prime} 00^{\prime \prime} \mathrm{E}$ \\
\hline WAM R81414 & Kununurra & $15^{\circ} 46^{\prime} 00^{\prime \prime} \mathrm{S}$ & $128^{\circ} 44^{\prime} 00^{\prime \prime} \mathrm{E}$ \\
\hline WAM R139398 & Ripon Hills & $21^{\circ} 14^{\prime} 00^{\prime \prime S}$ & $120^{\circ} 42^{\prime} 00^{\prime \prime} \mathrm{E}$ \\
\hline WAM R166244 & Walter James Range & $24^{\circ} 39^{\prime} 15^{\prime \prime} \mathrm{S}$ & $128^{\circ} 45^{\prime} 18^{\prime \prime} \mathrm{E}$ \\
\hline
\end{tabular}

Phylogenetic analysis by Bayesian inference of the aligned sequences was performed with MrBayes version 3.1.2 (Huelsenbeck \& Ronquist 2001; Ronquist \& Huelsenbeck 2003). Four data partitions were applied: the three codon positions in ND4 and the tRNA genes. The GTR $+\mathrm{I}+\mathrm{G}$ model of nucleotide substitution was found the most suitable model for each partition under the Akaike Information Criterion with Modeltest version (Posada \& Crandall 1998). Convergence of the MCMC was assessed from two exploratory runs of $1 \mathrm{x}$ $10^{6}$ generations with convergence assessed in AWTY (Wilgenbush et al. 2004) by: plotting log likelihoods of trees sampled every 500 generations against generation, plotting posterior probabilities (PP) of each split against generation after burnin trees were eliminated and by comparing posterior probabilities of each split between the two tree files after burnin trees were eliminated. MCMC chains had converged within 200,000 generations with a few splits with PP $<0.95$ showing about $10 \%$ variation in PP values post-burnin. Final MCMC analyses were performed in two runs of $5 \times 10^{6}$ generations with trees sampled every 500 generations. 


\section{Morphological analyses}

Table 2 lists details of voucher specimens examined for morphological comparisons. Standard body measurements and scale counts were made following Cogger (2000) and Storr et al. (2000). To determine the number and configuration of maxillary and palatine teeth we dissected the right side of the mouth by teasing the tissue away from the underlying teeth. X-ray radiographs were also used as a dry skeletal preparation was not possible with only one specimen. As we have no photographs or notes on the colour in life, all description of the colouration is taken from the preserved specimen.

Abbreviations used are: Qld — Queensland; QM - Queensland Museum, Brisbane; SA — South Australia; SAMA — South Australian Museum, Adelaide; SVL — snout-vent length; WA — Western Australia; WAM - Western Australian Museum, Perth.

\section{Results}

The aligned sequence dataset comprised 772 sites. A majority rule consensus tree derived from the final two Bayesian runs is shown in Fig. 2. WAM R166250 forms a strongly supported clade with the two described species of Oxyuranus (hereafter the Oxyuranus clade) and in particular is the strongly supported sister lineage to the two described Oxyuranus. Genetic distances among the three lineages range between $11.9 \%$ and $14.2 \%$ uncorrected sequence divergence. In contrast, inter-specific genetic distances among Pseudonaja range between $7 \%$ and $16 \%$ uncorrected sequence divergence. In contrast to the high levels of genetic divergence between the three lineages of the Oxyuranus clade, diversity within the two described species is low. In particular within $O$. scutellatus it is very low with eight haplotypes that differ by a maximum of $1.5 \%$ uncorrected sequence divergence present in the 19 specimens sequenced from eastern and northern Australia and New Guinea. Three haplotypes were found among the five $O$. microlepidotus collected from each of the two apparently separate populations of this taxon, i.e. Lake Eyre basin in South Australia and the Cooper basin in southwest Queensland and north-eastern SA. Uncorrected sequence divergence between these populations ranged from 2.8 to 3.1\%. The four Pseudonaja nuchalis sequenced from the same region as WAM R166250 cluster within one of the 'P. nuchalis' clades (Fig 2; see also Skinner et al. 2005).

Examination of the main characters for large terrestrial elapids in the keys of Cogger (2000) and Storr et al. (2000) indicated WAM R166250 had a combination of characters from Oxyuranus and Pseudonaja. The two genera each have characters thought to be derived with respect to Australian elapids in general. Pseudonaja species have lost the lower secondary temporal, evidently via fusion with the last upper labial scale, retain the plesiomorphic divided anal scale and have typical Australian elapid counts of 17 mid-body scale rows (most species; 17-19 in affinis, 19-21 in guttata). The maxilla is relatively long with numerous (often 810) small maxillary teeth following a relatively short fang. Known species of Oxyuranus retain a distinct lower primary temporal wedged between the second-last and last upper labial, have a derived single anal scale and have small body scales (in 23 rows, rarely in 21 or 25). The maxilla is shorter with few (1-3) small maxillary teeth following a relatively long fang. WAM R166250 has a single primary temporal, single anal scale and high midbody scale count of 21 (high for a Pseudonaja, low for an Oxyuranus). It has a single post-fang maxillary tooth, and in other respects (elongate head, high ventral count) is more like Oxyuranus than Pseudonaja. 


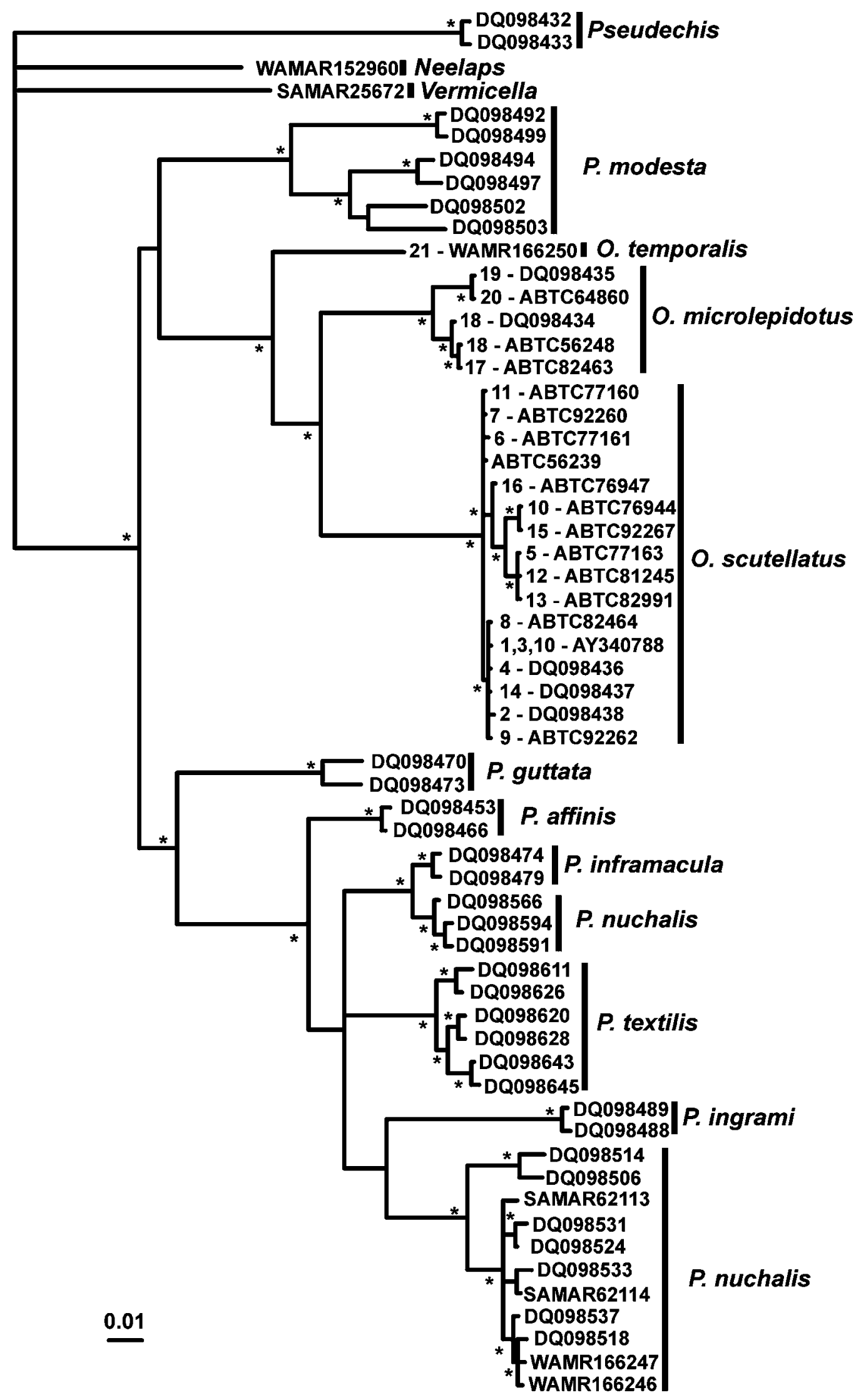

FIGURE 2. A majority rule consensus tree derived from the final two Bayesian runs showing phylogenetic relationships among mitochondrial ND4 haplotypes from Oxyuranus and Pseudonaja. Asterisks at nodes indicate posterior probabilities $\geq 0.95$. Terminal taxa are designated by GenBank Accession numbers or voucher registration numbers. Numbers at the start of each Oxyuranus specimen refer to collection locations in Table 1 and Fig. 1. 
We can suggest two hypotheses that might explain this blurring of the distinction between the two lineages: 1) WAM R166250 is a new species of Oxyuranus that shares some morphological character states with Pseudonaja; 2) WAM R166250 is an intergeneric hybrid between species of Pseudonaja and Oxyuranus. If the specimen is a hybrid, the female parent was an Oxyuranus, as the sequence is unambiguously placed as a sister to the known species of Oxyuranus. However, the same data show that this sequence is as divergent from the known species of Oxyuranus as they are from each other. Similarly, the area from which the specimen comes is remote from the known geographic range and habitat preferences of either known species of Oxyuranus. Therefore, if the specimen is a hybrid, the distinctive DNA sequence and habitat data are such that it in all likelihood the female parent was a previously unknown species of Oxyuranus, a conclusion not very different from hypothesis 1 . Two candidate species for the male parent of such a hybridisation occur sympatrically with WAM R166250, P. modesta and P. nuchalis. On the basis of adult body sizes $P$. nuchalis (max SVL $140 \mathrm{~cm}$ ) would be the more likely participant in an inter-generic mating with Oxyuranus than $P$. modesta (maximum SVL $52 \mathrm{~cm}$ ). Throughout their ranges, the two known species of Oxyuranus are sympatric with one or more species of Pseudonaja, but a wild hybrid has never been recorded. In spite of the fact that both Pseudonaja and Oxyuranus species have been widely kept as captives over many decades, no instance of a hybridisation between the two has been documented.

Of the two explanations, we find hypothesis 2 requires a more complex and unlikely set of circumstances than hypothesis 1 . We conclude that hypothesis 1, i.e. WAM R1616250 represents a hitherto unknown species of Oxyuranus, is the best explanation for our data. Under this view, the principal morphological anomaly is the temporal scale arrangement, which matches the apparently derived state seen in Pseudonaja. The cause of this homoplasy might be parallel evolution, with independent acquisition by Pseudonaja and the ancestor of WAM R166250, or reversal, with loss of the lower temporal in the common ancestor of Oxyuranus and Pseudonaja followed by re-expression of the lower primary temporal in O. microlepidotus and O. scutellatus. As noted above the precise branching order among these snakes is still poorly supported, so the choice between these explanations must await better resolution of the phylogeny of these snakes.

In the description below we provide a detailed morphological assessment of WAM R166250, which, based on the molecular genetic analysis and novel combination of morphological characters, we describe as a new species of Oxyuranus.

\section{Taxonomy}

Within the Australo-Papuan Elapidae, the specimen is diagnosable as a member of Oxyuranus (Covacevich et al. 1981; Cogger 2000; Storr et al. 2000) based on the following characters: undivided anal scale, paired subcaudals, high midbody scale rows (21), absence of suboculars, few maxillary teeth (1) and tail tip not ending in a soft spine. To this diagnosis we now add the presence of either one or two primary temporal scales.

Oxyuranus temporalis new species.

(Figs 3 \& 4)

Central Ranges Taipan

Holotype. WAM R166250 (SAMA field number BS-009075). A subadult female collected to the east of the Walter James Range, Western Australia (244'06”'S, $128^{\circ} 45^{\prime} 52^{\prime \prime}$ ), on 22 September 2006 by M. Hutchinson. Liver stored frozen at SAMA.

Diagnosis. A species of Oxyuranus distinguished from O. microlepidotus and O. scutellatus by one (rather than two) primary temporal scales and six (rather than seven) lower labials. 
Description of holotype. Measurements and counts: SVL-845 mm; tail length-125 $\mathrm{mm}(14.8 \%$ of SVL); head length (from rostral to back of parietal scale- $19.0 \mathrm{~mm}$; head width (at posterior edge of jaw) $12.1 \mathrm{~mm}$; Midbody scales in 21 rows at midbody (ventral 120), reducing from 31 behind the parietals, to 24 one head-length behind the head, to 17 one head-length in front of the vent; 250 ventrals; 60 subcaudals, all paired.

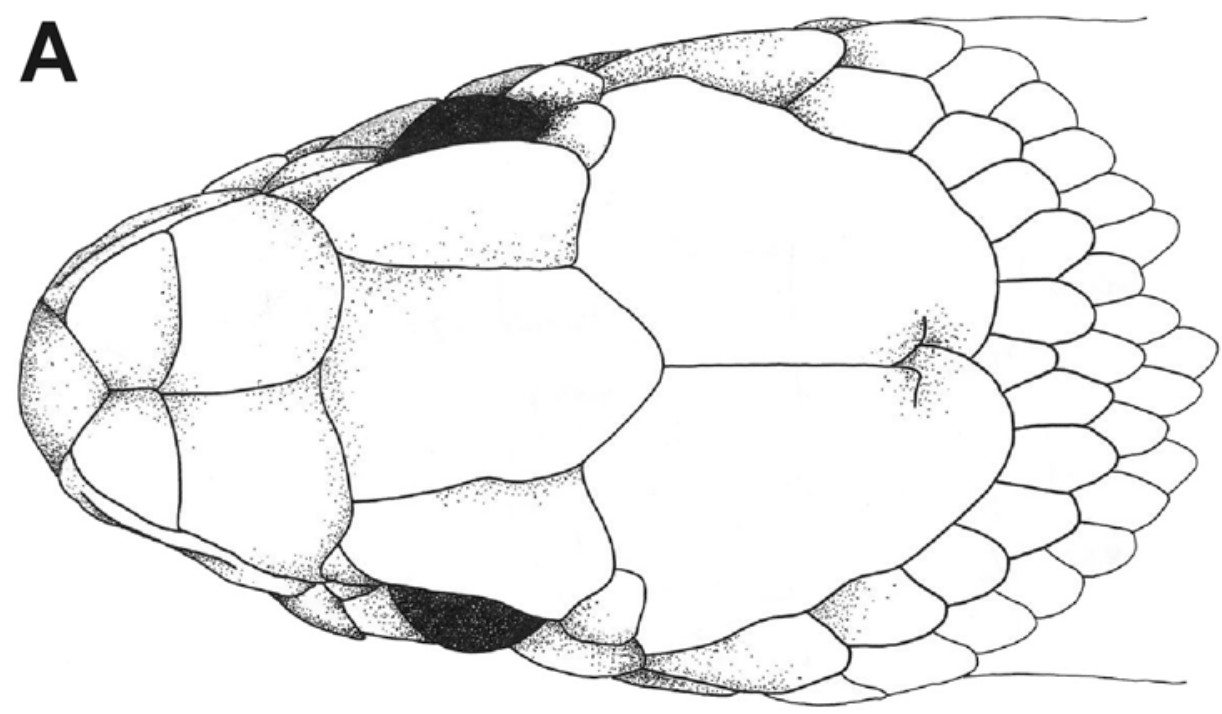

B

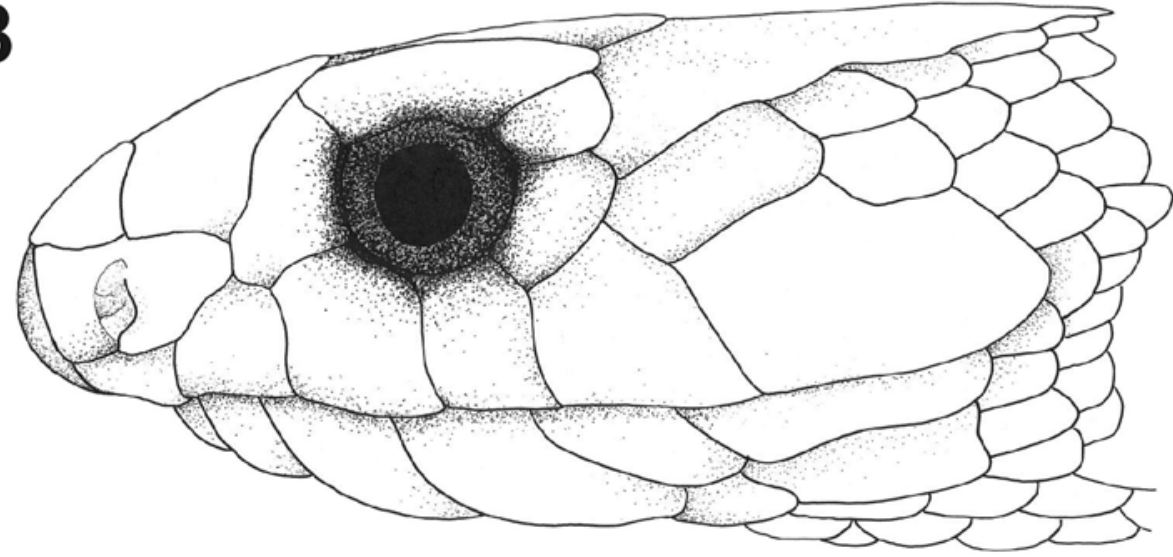

C

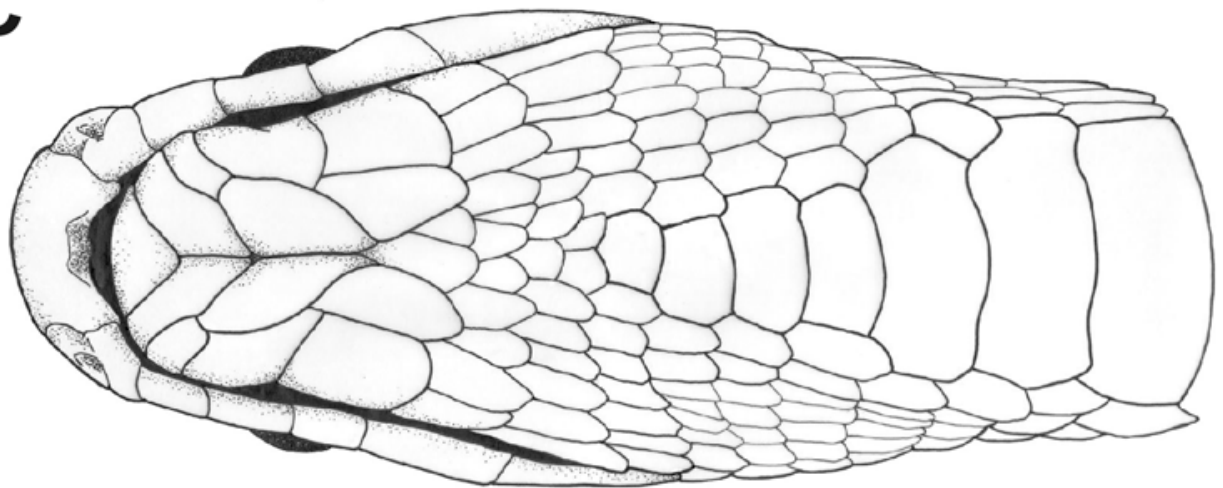

FIGURES 3 A-C: A, lateral; B, dorsal; and C, ventral head diagrams of the holotype of Oxyuranus temporalis sp. nov. (WAM R166250). 
Head distinct from neck. Tail elongate, tapering gradually from the cloaca. Scales smooth with a subtle convexity; no hint of keeling. Anal scale entire. Two pairs of pregenial and postgenial scales; anterior edge of pregenial in narrow contact with second lower labial; anterior edge of postgenial in narrow contact with third lower labial. Intergulars six and narrowing anteriorly towards chin; four gular scales between anterior most intergular and postgenial scales.

Head rectangular (sides parallel) tapering to a broadly rounded snout. Moderately sharp canthus rostralis and angular brow ridge that protrudes slightly beyond eye. Eyes large. Rostral scale large and arched dorsally; lingua fossa large and circular. Nasals entire, perforated by large nostril that opens posteriorly. Margin of nostril just reaches ventral border of nasal. Internasals squarish and approximately half the length of the prefrontals. Prefrontals large and as wide as long. Sides of frontal slightly concave, width of anterior edge slightly smaller than length, posterior edges converging at $45^{\circ}$ angles. Supraoculars 2.5 times longer than wide, gradually narrowing anteriorly (1.5 times longer than prefrontals). Preocular twice as high as wide, separated from frontal but ventral anterior edge extends to contact nasal. Two postoculars, lower about twice as high as upper. A single primary temporal scale with two secondary temporals. Parietals large, longer than wide; short medial transverse suture located near posterior edge of scales. Upper labials 6; lower labials 6 (7 if small scale below sixth upper labial is counted; see Fig. 3). Labials have a slightly serrated appearance along jaw. Last upper labial large and rectangular except for encroachment of lower secondary temporal into dorsal posterior corner. Right front fang $3.0 \mathrm{~mm}$ long (left fang broken inside sheath). A single tooth follows the fang on the maxilla. Palatine with a toothless portion anteriorly, followed by approximately 8 teeth (estimated from partial dissection). 10 dentary teeth.

Colouration in preservative. Body is light pale brown with diffuse darker olive grey variegations (Fig. 4). Head creamy brown and distinctly paler than body. No dark collar separating the pale head from the browner body colour. The skin from many scales has sloughed off revealing a pale whitish underlying ground colour with darker olive grey scales maintaining contrast to ground colour. Ventral surface pale yellowish white; no yellow tinge on subcaudals. Slight indication of spotting on ventral surface towards head. Eye black with black iris, pupil round. Lining of mouth pale.

Reproduction and diet. It is likely that the female was approaching maturity as there are four undeveloped follicles in the left ovary (largest $=2.87 \mathrm{~mm}$ ) and three in the right ovary (largest $=3.18 \mathrm{~mm}$ ). Size at maturation in the other species of Oxyuranus is close to the size of the holotype (Shine \& Covacevich 1983). Numerous fat bodies are present. Dissection of the gut revealed several clumps of hair from recent small mammal prey items.

Habitat and behaviour. The specimen was captured on a hot sunny day crossing a dirt road on a deep sandy flat with very open low mallee (Eucalyptus spp.) and Grevillea over storey and diverse shrubby understorey dominated by Triodia. The snake was sighted from a motor vehicle, at approximately $1600 \mathrm{~h}$. When the vehicle passed the snake and stopped, the snake remained immobile rather than fleeing, and when approached it adopted an "S" threat pose typical of Pseudonaja and Oxyuranus (M. Hutchinson, pers. obs.)

Distribution. The holotype was collected on the eastern margin of the Walter James Range of Western Australia near the borders of Northern Territory and South Australia (Fig. 1). Further specimens need to be encountered before the extent of the distribution of $O$. temporalis is determined.

Comparison with other species. Comparisons with other species are limited owing to only a single specimen of O. temporalis. Below we comment on the most obvious characters not likely to greatly vary within species.

Oxyuranus temporalis is distinguished from the sympatric and related large elapids Pseudechis australis and Pseudonaja nuchalis by 21 (versus 17) midbody scale rows, undivided anal scale and greater number of ventrals $(250$ versus < 230). These characters also distinguish $O$. temporalis from Pseudonaja modesta that has a much smaller body size and usually some indication of dark rings on body. Oxyuranus have more intergulars than Pseudonaja nuchalis as well (Fig. 5). 

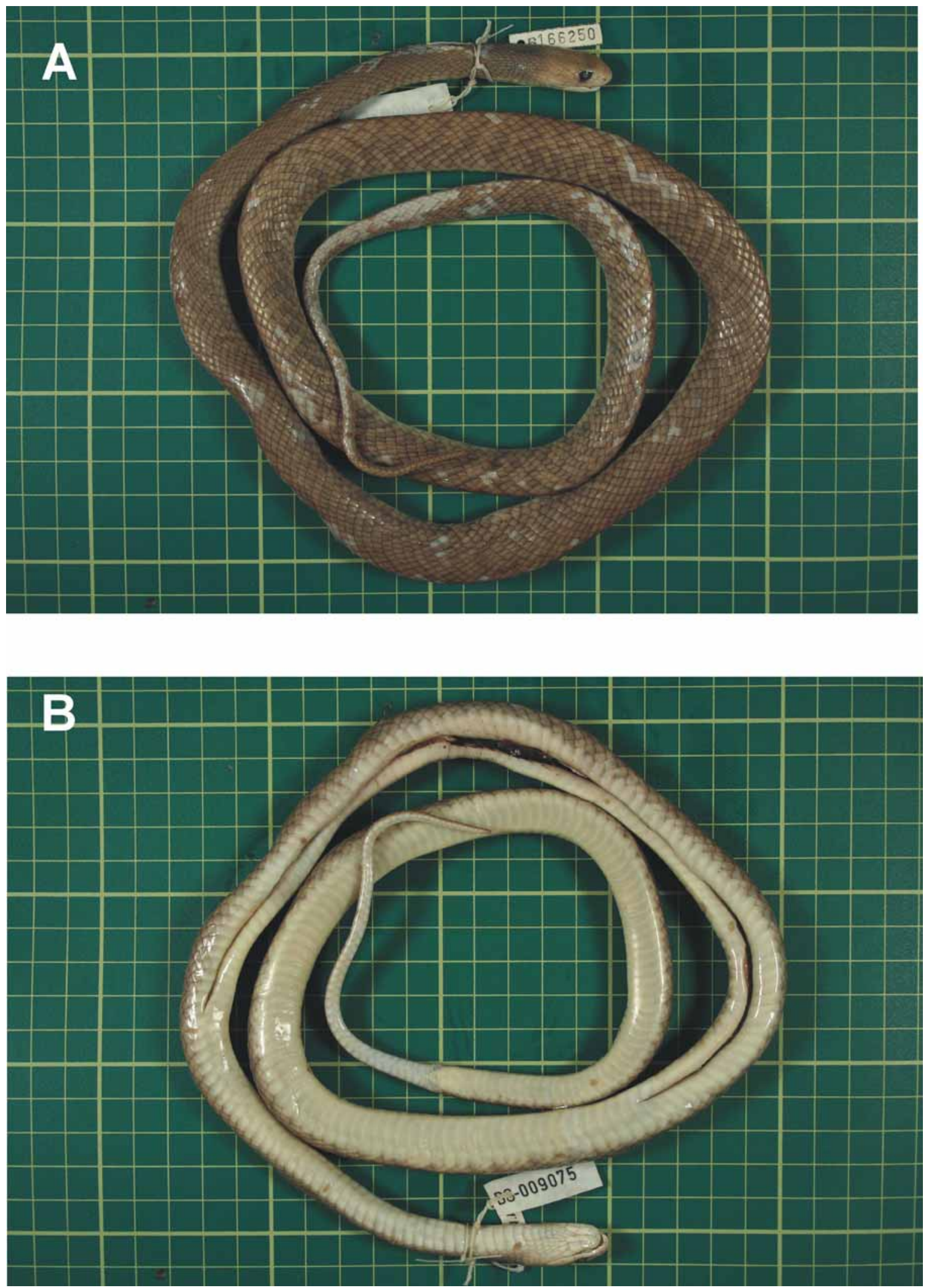

FIGURES 4 A-B: A, Dorsal and B, ventral photographs of the holotype of Oxyuranus temporalis sp. nov. (WAM R166250).

Within Oxyuranus, O. temporalis differs from $O$. microlepidotus and $O$. scutellatus by possessing a single primary temporal scale. In the other two species, as in most Australian elapids, there is a second primary tem- 
poral, penetrating deeply between the sixth and seventh upper labials. There are seven lower labials in $O$. scutellatus and $O$. microlepidotus whereas there are six in $O$. temporalis. In most $O$. microlepidotus and $O$. scutellatus, the nasal and preocular are separated or in narrow or point contact. In O. temporalis, the contact is more extensive but, given the variation observed in the other two species, this condition needs to be examined in more specimens of $O$. temporalis. Oxyuranus temporalis has a single post-fang maxillary tooth, similar to the state seen in $O$. scutellatus, whereas $O$. microlepidotus has 3-5. Oxyuranus temporalis can be further distinguished from $O$. microlepidotus by fewer midbody scale rows (21 versus 23-25) and from $O$. scutellatus by the possession of smooth (versus keeled) anterior dorsal scales.

Etymology. From the Latin temporalis in reference to the different arrangement of temporal scales compared to the other two species of Oxyuranus.

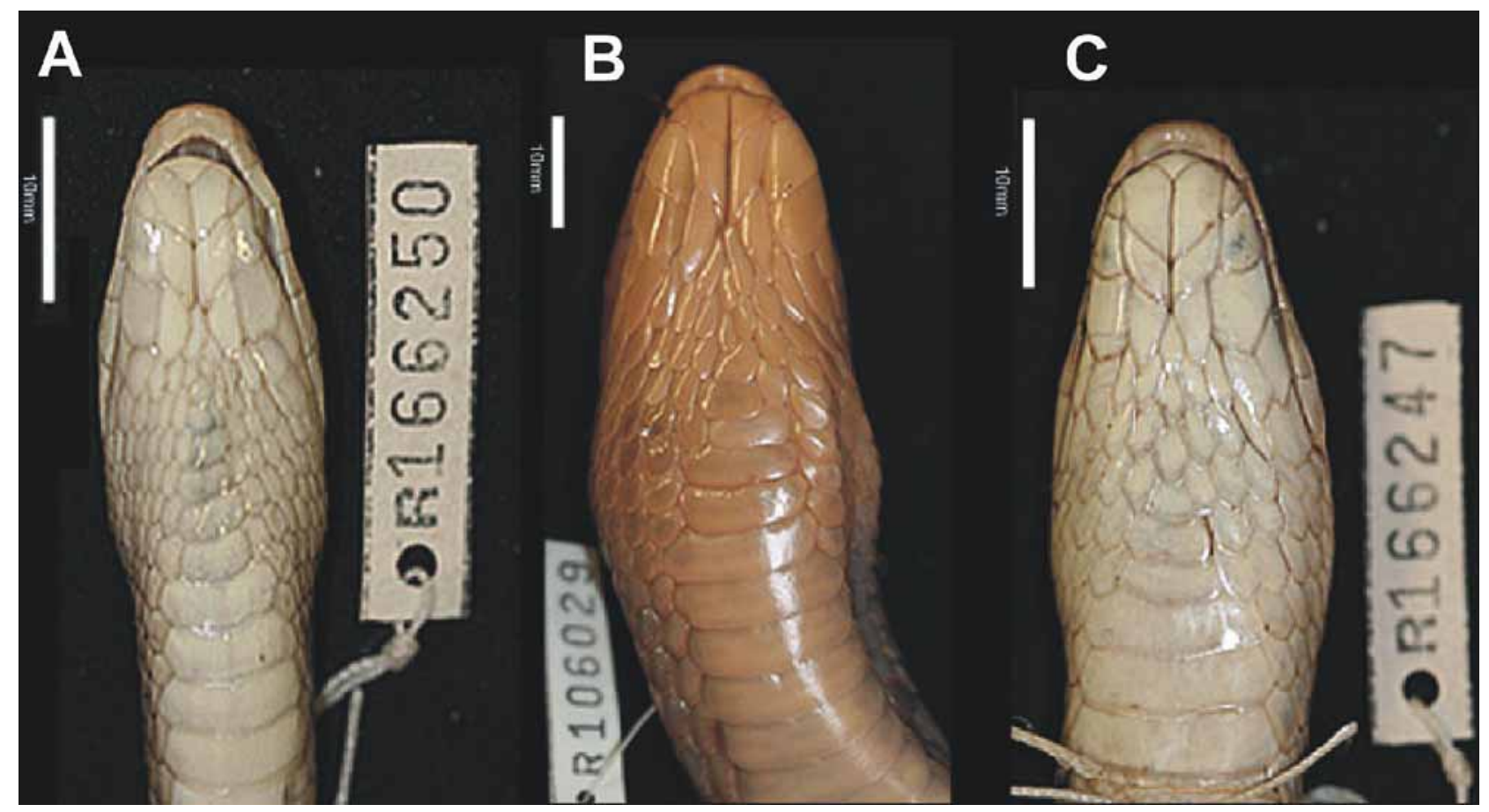

FIGURES 5 A-C: Comparison of gular regions of A, Oxyuranus temporalis sp. nov. (WAM R166250), B, O. scutellatus (WAM R106029) and C, Pseudonaja nuchalis (WAM R166247).

\section{Discussion}

Oxyuranus temporalis is a distinctive species of taipan. The molecular data support $O$. temporalis as the sister species of $O$. microlepidotus plus $O$. scutellatus, but the latter two species are also strongly divergent from one another. All three taipans are well supported as a monophyletic group (posterior probability 1.00) with respect to their nearest relatives in Pseudonaja. The mix of morphological character states seen in the holotype of O. temporalis reduces the number of features that separate Oxyuranus from Pseudonaja. In scalation (single primary temporal) and colour (spotting, albeit weak, on the belly), this species is more like Pseudonaja than the other Oxyuranus. While our phylogenetic analysis found a paraphyletic Pseudonaja, i.e. the Oxyuranus clade is embedded within Pseudonaja, it should be noted that our result was not strongly supported (see relevant node in Fig. 2) and that it conflicts with the findings of Skinner et al. (2005) who analysed a much larger number of sequences and found the two genera to be reciprocally monophyletic. Also we used a different combination of outgroups to Skinner et al. (2005). Taken together these results suggest that the relationships between Pseudonaja and Oxyuranus as determined from analysis of mitochondrial DNA are sensitive to 
taxon sampling and should conservatively be regarded at present as not different from the conventional taxonomic arrangement of these taxa, i.e. two lineages.

The large genetic distances among the three species coupled with their disparate distributions (northern and eastern coast [O. scutellatus], eastern arid zone [O. microlepidotus] and western central ranges [O. temporalis]) suggest taipans were once more widespread in Australia. Climate change, competition from other snakes such as Pseudonaja and Pseudechis australis or changes in the distribution and abundance of mammalian prey may have resulted in their current relictual distributions. Almost nothing is known of the biology, habits and ecology of O. temporalis. The other two species of taipans are the largest terrestrial elapids in Australia and among the most venomous species in the world. How $O$. temporalis compares to O. microlepidotus and $O$. scutellatus will rely on encounters with more specimens of $O$. temporalis to determine maximum size and to obtain venom samples to test their potency. The rate of discovery of further information on the biology of O. temporalis may follow a similar slow course to that of the other taipans owing to the former's remoteness in central Australia (Covacevich 1987).

The discovery of a third species of taipan after more than 125 years since the last species was described is testament to the large expanses of the Australian arid zone that remain poorly surveyed for reptiles. There are likely to be other undescribed species of reptiles in these parts of north-eastern Western Australia and western Northern Territory that have rarely been visited by biologists.

\section{Acknowledgments}

We thank the Ngaanyatjarra Council and traditional owners from Warakurna and Tjukurla communities for permission to access their lands and for their collaboration during survey work in 2006. Special thanks to E. Bennett, T. Mitchell, P. Lewis, J. Lewis, N. Jackson, J. Golding/Chambers, A. Porter, E. Porter, D. Bennett, K. Butler, M. Young and D. Butler. Thanks also to Ngaanyatjarra Council staff, Mr. and Mrs. Butler, J. Miller, D. Newham, A. Hunt, B. Jennings, J. Turner, P. Ramsay and A. Knight for their assistance with liaison and organisation. D. Pearson and I. Kealley (Department of Environment and Conservation) were instrumental in providing key logistical help and coordination for the expedition, as did the expedition members from the Western Australian Museum, South Australian Museum and DEC. Funding was provided by a grant from H. and M. Butler, Ngaanyatjarra Council Land Management Unit, and through C. Slatyer of the Department of Environment and Heritage, Canberra, and to the Ngaanyatjarra Council Native Title Unit for in-kind support. We thank K. Aplin, S. Eipper, A. Emmott, P. Horner, T. Schwaner, R. Stannard, D. Trembath, P. Tremeul, J. Wombey and staff of the Qld EPA Cairns office for provision of samples for the molecular analyses, R. Foster and L. Wheaton for the nucleotide sequencing and S. Keogh for providing some of the outgroup sequences. We thank C. Stevenson for the head drawings, chin photographs and map, K. Sullivan for the holotype photographs, S. Knott and S. Morrison (WAM) for the X-rays and R. How for the reproductive and diet assessments. P. Couper kindly provided scale counts on a sample of O. microlepidotus. R. Sadlier, A. Amey, C. Kovach and P. Horner provided locality data for the distribution map. We thank the reviewers and C. Gregory, B. Bush, G. Shea and R. How for lively discussion.

\section{References}

Aplin, K.P. \& Donnellan, S.C. (1999) An extended description of the Pilbara death adder, Acanthophis wellsi Hoser (Serpentes: Elapidae), with notes on the desert death adder, A. pyrrhus Boulenger, and identification of a possible hybrid zone. Records of the Western Australian Museum, 19, 277-298.

Barnett, B. (1978) Taipan (Oxyuranus scutellatus). Victorian Herpetological Society Newsletter, 9, 16-20.

Barnett, B. (1986) The taipan (Oxyuranus scutellatus) in captivity. Thylacinus, 11, 9-19. 
Broad, A.J., Sutherland, S.K., Taner, C. \& Covacevich, J. (1979) Electrophoretic, enzyme, and preliminary toxicity studies of the venom of the small-scaled snake, Parademansia microlepidota (Serpentes: Elapidae), with additional data on its distribution. Memoirs of the Queensland Museum, 19, 319-329.

Cogger, H. (2000) Reptiles and Amphibians of Australia, sixth edition. Reed Books, Sydney, 775 pp.

Covacevich, J., McDowell, S.B., Tanner, C. \& Mengden, G.A. (1981) The relationship of the taipan, Oxyuranus scutellatus, and the small-scaled snake, Oxyuranus microlepidotus (Serpentes: Elapidae). In Banks, C. B. \& Martin, A. A. (Eds), Proceedings of the Melbourne Herpetological Symposium 1980. The Melbourne Zoological Board, Parkville, 160-168.

Covacevich, J. (1987) Two taipans! In Covacevich, J., Davie, P. \& Pearn, J. (Eds), Toxic plants \& animals - A Guide for Australia. Queensland Museum, Brisbane, 480-485.

How, R.A. \& Cowan, M.A. (2006) Collections in space and time: a biogeographical examination of native frogs, mammals and reptiles in Western Australia. Pacific Conservation Biology, 12, 111-133.

Huelsenbeck, J.P., \& Ronquist, F. (2001) MRBAYES: Bayesian inference of phylogeny. Bioinformatics, 17, 754-755.

Jones, P. (1977) Search for the Taipan, the Story of Ram Chandra. Angus and Robertson, Sydney, $112 \mathrm{pp.}$

Keogh, J.S. (1998) Molecular phylogeny of elapid snakes and a consideration of their biogeographic history. Biological Journal of the Linnaean Society, 63, 177-203.

Keogh, J.S. (1999) Evolutionary implications of hemipenal morphology in the terrestrial Australian elapid snakes. Zoological Journal of the Linnaean Society, 125, 239-278.

Keogh, J.S., \& Smith, S.A. (1996) Taxonomy and natural history of the Australian bandy-bandy snakes (Elapidae: Vermicella) with the description of two new species. Journal of Zoology (London), 240, 677-701.

Keogh, J.S., Shine, R., \& Donnellan, S. (1998) Phylogenetic relationships of terrestrial Australo-Papuan elapid snakes based on cytochrome b and 16S rRNA sequences. Molecular Phylogenetics and Evolution, 10, 67-81.

Keogh, J.S., Scott, I.A.W., \& Scanlon, J.D. (2000) Molecular phylogeny of viviparous Australian elapid snakes: Affinities of 'Echiopsis' atriceps (Storr, 1980) and 'Drysdalia' coronata (Schlegel, 1837), with description of a new genus. Journal of Zoology (London), 252, 317-326.

Kinghorn, J.R. (1955) Herpetological notes, number 5. Records of the Australian Museum, 23, 283-286.

McCoy, F. (1879) Diemenia microlepidota, small-scaled snake. Prodromus of the Zoology of Victoria, 3, $12-13$.

O'Shea, M. (1996) A guide to the snakes of Papua New Guinea. Independent Publishing, Port Moresby, 239 pp.

Posada, D. \& Crandall, K.A. (1998) Modeltest: testing the model of DNA substitution. Bioinformatics, 14, 817-818.

Ronquist, F. \& Huelsenbeck, J.P. (2003) MRBAYES 3: Bayesian phylogenetic inference under mixed models. Bioinformatics, 19, 1572-1574.

Shine, R. \& Covacevich, J. (1983) Ecology of highly venomous snakes: the Australian genus Oxyuranus (Elapidae). Journal of Herpetology 17, 60-69.

Skinner, A., Donnellan, S.C., Hutchinson, M.N. \& Hutchinson, R.G. (2005) A phylogenetic analysis of Pseudonaja (Hydrophiinae, Elapidae, Serpentes) based on mitochondrial DNA sequences. Molecular Phylogenetics \& Evolution, 37, 558-571.

Slowinski, J.B. \& Keogh, J.S. (2000) Phylogenetic relationships of elapid snakes based on cytochrome b mtDNA sequences. Molecular Phylogenetics \& Evolution, 15, 157-164.

Smith, L. A. (1981) A revision of the python genera Aspidites and Python (Serpentes: Boidae) in Western Australia. Records of the Western Australian Museum, 9, 211-226.

Smith, L.A. (1982) Variation in Pseudechis australis (Serpentes: Elapidae) in Western Australia and description of a new species of Pseudechis. Records of the Western Australian Museum, 10, 35-45.

Stackhouse, J. (1970) Australia's Venomous Wildlife. Summit Books, Sydney, 144 pp.

Storr, G.M., Smith, L.A. \& Johnstone, R.E. (2000) Snakes of Western Australia. Western Australia Museum Publications, Perth, 309 pp.

Wilgenbusch J.C., Warren D.L. \& Swofford D.L. (2004) AWTY: A system for graphical exploration of MCMC convergence in Bayesian phylogenetic inference. http://ceb.csit.fsu.edu/awty.

Worrell, E. (1958) Song of the Snake. Angus and Robertson, Sydney, $210 \mathrm{pp}$.

Wüster, W., Dumbrell, A.J., Hay, C., Pook, C.E., Williams, D.J. \& Fry, B.G. (2005) Snakes across the Strait: Trans-Torresian phylogeographic relationships in three genera of Australasian snakes (Serpentes: Elapidae: Acanthophis, Oxyuranus and Pseudechis). Molecular Phylogenetics \& Evolution, 34, 1-14. 